\title{
Impact of Music Education at Colleges of Education on Primary School Pupilsin Nanumba North District
}

\author{
${ }^{1}$ Eric Kwadzo Klutse ${ }^{*}{ }^{2}$ Eddison Foster Mawusi, ${ }^{3}$ Solomon Sukpen \\ ${ }^{1,2,3}$ MPhil. E. P. College of Education, Bimbila. Ghana W/A
}

\begin{abstract}
This This paper presents how music education in the Colleges of Education influences the teaching of Music and Dance on the primary school. This study aimed to evaluate the training of the student-teachers in preparation to teach Music and Dance as well as to explore the relationship between Music Education at the Colleges of Education and the primary schools. Qualitative method was used and data were obtained through interviews and observations. Fifteen (15) respondents were selected from three (3) schools in the Nanumba North District - Bimbila were randomly sampled for the study. Findings revealed that the amount of training or preparation received in Colleges of Education has been inadequate and has no influence on what entails in the Creative Arts (Music and Dance) syllabus. Hence making teachers handicapped in handling Music and Dance lessons. The work recommends that more attention should be given to teacher preparation in Music and Dance in terms of contents and the methodology to meet the demands of Creative Arts (Music and Dance) syllabus. Also, there should be a revision of subjects that comprise Creative Arts in the Colleges to conform to Creative Arts in the primary school.
\end{abstract}

Keywords: Creative Arts, Music and Dance, Note values, Membranophones, Labanotation, Idiophones, Chordophones and Aero phones

\section{Background to the Study}

The Creative Arts subject is one of the key learning areas within the primary curriculum which is a very essential component of every primary school across the world. Though uniquely different in appearance and method from each other, each discipline employs similar cognitive processes, ultimately allowing language and thought to be expressed through a variety of representations. Engaging children in the Creative Arts can allow them to communicate in potentially profound ways (Eisner, 2002). As Russel-Bowie (2009) points out that because the arts can embody and communicate emotions, ideas, beliefs and values, they can convey meaning through aesthetic forms and symbols and evoke emotive responses to life with or without words. Evidence abounds that Creative Arts learning and engagement has a range of positive outcomes in terms of the lives of young people both in and out of school settings (Bamford, 2006; Catterall, Chapleau\&Iwenaga, 1999; Deasy, 2002; Fiske, 1999). Despite the benefits derived from learning of Creative Arts, the subject matter remained marginalized, especially Music and Dance as part of the components of Creative Arts syllabus in the primary schools.

Music and Dance plays a central role in the lives of young people everywhere. It shapes their social identities and the ways in which they relate to each other. The Creative Arts of which Music, Dance and Drama (Performing Arts) is part of a powerful tool of communication. They always relate easily to aspects of every subject or topic in the curriculum. Ebeli, (2015) argues that, the production of musical sound from the singing of traditional songs, the production of sound from the accompanying instruments, and the dance movements transmit something which carries messages. In other words, Music, Dance and Drama when performed always provide some sort of education to the people. Manford, (2007) asserts that music is a powerful tool in expressing thoughts people nurture in mind, how they feel, their norms and values, and how they generally live. Music, Dance and Drama are undividable in Ghanaian society since these subjects complement each other in enforcing moral behaviour and values. This statement reinforces the idea behind the Creative Arts Syllabus for Primary Schools in Ghana which integrates Music, Dance and Drama for the Music component of the subject. 
Music and Dance is an integral part of every young child's intellectual, cultural,emotionaland spiritual development and should not be treated in isolation from the rest of the curriculum. To include Music and Dance across that curriculum will provide pupilswith experiences that will broaden their thinking and facilitate a deeperunderstandingof the world or environment in which they live and to inform pupils about their cultural heritage. Ross, (1984) argues that education becomes meaningless if it fails to provide students with an understanding of their experiences. By the same token, education fails if it does not help pupils understand their musical experiences (Tait, 1992). Every pupil in the classroomshould be involved and encouraged in some form of music making. Music is not just for themusically gifted or able performers but needs to be differentiated. It is partof our lives and enriches our everyday experiences in thinking and feeling and pupils in public primary schools in Nanumba North District are no exception.

Nanumba North District is one of the 26 districts in the Northern region of Ghana. It was created as a separate District in 2004 when the then Nanumba District was split into two, north or south with an area of 2260.8 square/ kilometers. The district shares boundaries with East Gonja to the west, Yendi Municipal to the north. To the east, it shares boundary with Zabzugu, the south with Damanko (Volta region) and to the south east, Nanumba South District. The administrative district capital is Bimbilla and their main occupation is agriculture. The District currently has 62 kindergarten (KGS) and nursery schools, 92 primary (5 private and 87 public) schools, 23 Junior High Schools (JHS), two Senior High schools (SHS) and one College of Education. The district has a total number of 405 teachers out of which 190 are professional and 215 nonprofessional trained teachers. There are some volunteer teachers under the National Youth Employment Programme (NYEP).

Music and Dance as a subject in the primary schools in Ghana has actually been going through challenges for ages. Aduonum (1980) asserts that like the early music education system in United States, so the music education in Ghana has been limping on one leg for many years. But Ogbe (1975) describes the situation vividly that the state of music education in Ghana casts an image of a splendid superstructure on a very weak foundation. The reality about music education in most primary schools in Nanumba North District is the true reflection of both statements above and the only place music is considered important by primary school teachers is when schools celebrate festival of Arts that require the performances of drumming, dancing and singing.

Colleges of Education in Ghana were set up to train or prepare quality teachers to teach any Ghanaian child of school going age; and the quality preparation of Music and Dance teachers in the Colleges is to enhance quality teaching and learning of Music and Dance in the primary schools. Therefore, a number of well trained teachers graduate every year since time immemorial in anticipation to change or improve the present state of Music education in Ghanaian primary schools. The quality of teaching is directly linked to the quality of the pre-service teacher's preparation (Darling-Hammond, 2000). This is particularly true for teaching music (Ballantyne, 2005). Pre-services teachers need to develop a number of attributes in relation to pedagogy, content, ability, confidence, student learning, classroom management and their ability to selfreflect. Through expanding pre-service teacher's knowledge and music awareness teachers will be better able to implement music in the classroom (Joseph \& Heading, 2010).

\section{Statement of the Problem}

The United Kingdom National Plan for music education (2011) agrees with Aristotle who states "Music has the power of forming the character and should therefore be introduced into the education of the young". If this assertion is anything to go by, then teachers ought to be well equipped with the contents of the subject area and the mastery of methods to help them to be effective in their delivery. However, prior visit to some primary schools in the Nanumba North District (Northern Region) for supervision of out- programme student teachers and subsequent discussion with most teachers reveals that, in almost all the schools the researcher has been to for the supervision none of them taught Creative Arts (Music and Dance) as a subject.Flolu and Amuah (2003) affirm that the history of music education in Ghana is not that of achievements, and changes; rather it is a history of difficulties, a history of missing link between school education and the local environment, a history of struggle for cultural identity and cultural preservation. Music educators always cry aloud over this problem instead of finding a lasting solution to it. Colleges of Education in Ghana are solely responsible for training teachers to go out there to teach, implement the 
various curriculum subjects including Music and Dance as a component of Creative Arts syllabus at the primary school levels. As a matter of fact, Music and Dance taught in Colleges should have influence on Music and Dance in the primary school, but a closer look shows that teachers find it difficult in teaching Music and Dance aspect in the Creative Arts syllabus. Hence this research is to find out if there isa relationship in Music contents at the Colleges and the primary schools. Meanwhile the importance of Music and Dance in the upbringing of school children has been proven and tested by many music educators.

\section{Purpose of the Study}

The purpose of this study is to examine the influence of Music Education in College of Education on the teaching of music at the primary schools.The knowledge and skills of every Creative Arts (Music and Dance) teacher is the benefits pupils stand to gain from their teaching of Creative Arts (Music and Dance) in their classrooms and these will empower and enhance the teachers to be efficient in their delivery. Generally, children stand to gain a lot from the study of Creative Arts (Music and Dance) in the primary schools, therefore teachers should be in the position to help these pupils to experience the benefits of making music in their classroom and teachers cannot achieve these without having foreknowledge about the subject area.

\section{Objectives}

The study focuses on the following objectives:

- To evaluate the training of the student teacher in preparation to teach Music as a component of the Creative Arts syllabus.

- To explore the relationship between Music at the Colleges of Education and the primary schools.

- To examine the kind of instructional materials employed in the teaching and learning of music at the primary level.

- To examine the extent to which, college music impact the teaching of music in primary schools.

\section{Research Questions}

The following research questions were designed and used to direct the course of the study as:

- What training do the student teachers receive in preparation to teaching music in the creative arts syllabus?

-What is the relationship between Music Education at the colleges of education and the primary school?

- What kind of instructional materials are employed in the teaching and learning of Music at the basic school?

- To what extend does college Music impact the teaching of Music at the primary school?

\section{Significance of the Study}

This research seeks to contribute useful suggestions to teachers teaching Creative Arts (Music and Dance) on things that they should do as Music and Dance teachers. Also, it will encourage teachers teaching at the various Colleges to teach concepts of topics rather than preparing the trainee teachers to just pass end of semester examination. Furthermore, it would be useful for the purpose of curriculum review in future. This study will guide curriculum planners to link what goes on at the Colleges with what pertains in the primary schools Creative Arts syllabus (Music and Dance).

\section{Research Design}

In this study the researcher used Case study design. Case study "often focuses on a classroom, group, teacher or pupil, using a variety of observation and interview methods as their major tools" Burns, (2000). Fisher (2004) suggests that case studies are more appropriate for an in-depth understanding of a particular situation. The strength of the case study approach is in its ability to examine a "full variety of evidence documents, artifacts, interview, and observations" (Yin, 2003, p. 8).A case study was chosen because it provided an account of all activities of problem that contained anactual situation encountered in the workplace. Case studies are used to help see how the complexities of real life influence decisions.

\section{Population}


The target population for this study comprised all Primary school teachers teaching Creative Arts (Music and Dance) in the Nanumba North District, Bimbilla in the Northern Region of Ghana.According to White (2003, p.57), a population is "a collection of objects, events or individuals having the same characteristics that the researcher is interested in studying". Berg (2009) suggests that, the researcher must identify a population that is appropriate for the study, not merely an accessible one. The District is divided into six (6) circuits, namely; Bimbilla East, Bimbilla West, Bimbilla Rural, Chamba, Makayili and Bincheratanga. Currently, there are eighty-seven (87) primary schools with a total number of one hundred and ninety (190) professional teachers in the District which cannot be used for the study since that is too much to assume.

\section{Sample size}

Out of eighty-seven (87) public primary schools in the district, three (3) of them were used with a minimum sample size of fifteen (15) primary school teachers as respondent out of one hundred and ninety (190) teachers in the district. This is in line with Creswell (2012) who acknowledges thatwhen selecting participants for study, it is important to determine the size of the sample you need. Bryman (2012) holds the view that, in qualitative research sample size should not be so small but again not so large that it is difficult to undertake a deep case-oriented analysis. From that effect, the researcher decided to selecta reasonable sample size of fifteen (15) respondents using random sampling (lottery method) that could be handled given the amount of time and resources available. The number of respondents was seen to be conveniently decided because the researcher was of the view that he would elicit enough information from them. This is also supported by Check and Schutt (2012) who argue that it is important to pick a smaller sample from a larger population because student researchers usually lack both time and money to undertake researchinvolving larger samples. Therefore, the researcher sees it appropriate to select three (3) primary schools in the District for the study. The selected primary schools were E.P Demonstration Primary School (A), Our Lady Primary School (B) and Kpabi D/A Primary School (C) in and around Bimbila.

\section{Theoretical Framework}

Motivation refers to the process through which goal-directed activity is initiated and sustained. Motivation influences learning of new behaviors and performance of previously learned behaviors (Pintrich\&Schunk, 2002). Learning and performance are related in a reciprocal fashion to motivation because what one does and learns influences one's subsequent task motivation. This study relies on Bandura's $(1977,1986)$ social cognitive theory of motivation as a lens through which to view student-teachers' ability to teach music and dance in the primary school. Of the factors that motivate individuals, perhaps none are more influential than perceived beliefs of competence. Bandura's theory explains the development of attitudes from a social learning framework in which behavior is theorized to depend on one's sense of self-efficacy $(1977 ; 1997)$. Self-efficacy perception, or belief in one's ability to perform a particular task, differs from other forms of self-belief in its specificity to a defined skill, activity, or domain.Because of its specific focus, it has been shown to be a more consistent predictor of achievement than other more general forms of self-belief. Restated, self-efficacy is the belief in one's own ability to conduct the behavior in question. Bandura emphasizes that self-efficacy is a situation specific determinant of an individual's behavior and not a global personality trait.

Our choices of action, behavior, and pursuits, the amount of effort and level of endurance we devote to an activity, and the level of accomplishment we attain are all influenced by our belief in our personal efficacy (Bandura, 1997). Although music scholars have studied various forms of motivation, a surprising void remains in music education research investigating the topic of self-efficacy, a competence self-belief that has proven to be profoundly powerful in predicting outcomes for a variety of endeavors (Bandura, 1997; McPherson \& McCormick, 2006; Pajares, 2006; Zimmerman, 2000). The present research therefore observes self-efficacy perception within the context of a post-secondary music methods course, in order to ascertain the influence of personal competence beliefs upon the development of both music ability and confidence to teach music.Bandura (1986) noted in his work on teaching processes that self-efficacy is the strongest predictor of motivation and beliefs. The individual's efficacy beliefs are instrumental in defining tasks and selecting cognitive tools with which to interpret, plan and make decisions that individuals make throughout their lives. The successful implementation of quality music programs in primary school settings depends in large measure on teachers' sense of personal music teaching self-efficacy, that is, their personal beliefs about their ability to teach music and dance and their ability to produce positive outcomes in music 
for children. Student-teachers' enter teacher education programs with established attitudes, beliefs, values, and their own sense of personal teaching self-efficacy. A perceived lack of preparation has been shown to produce negative attitudes toward music in repressive teachers and a lack of confidence in their ability to teach music (e.g., Barry, 1992; Gifford, 1993; Jeanneret 1997; Mills, 1989). The consequence is the avoidance of teaching music and/or ineffective teaching.

\section{Teacher Education Music Programme}

Currently, there is a great gap between what tutors teach on the course and what student teachers need to practise in primary classrooms; that is, a basic failure to relate the theoretical and practical knowledge of student teachers. Again, the difference between how students are to be taught at their courses in the colleges and how student teachers should actually use the skills and knowledge acquired in primary schools seems to be the main concern. In other words, the gap between the course content and primary school music content appears to be the biggest problem during Music teacher education courses, which may have resulted in teachers' lack of poise in their ability to teach Music and Dance due to unrepresentative teacher education course curriculum.

Durrant and Welch (1995) emphasize that if teachers recognize their own musical potential as well as their pupils, they would be in a better position to facilitate effective musical learning and understanding. This can be implemented by creating a classroom atmosphere, which is friendly and supportive, encompassing active participation and group activities. Children's music learning can be fun using different musical activities and musical styles, and this can increase their inner confidence. To be able to practise music in this environment, as Durrant and Welch (1995) stress is to do with the attitude of teachers and their perceptions about themselves as musicians and music facilitators.However, potential primary teachers may face difficulties in their own music learning and teaching; initially, at the beginning of their training because of existing beliefs about their musical achievements, and then during their primary school teaching, where school and staff attitudes and beliefs focus around the commonly held hereditarian view that musical ability depends on an inborn gift. In other words, if they have not been bestowed with some general musical ability, their achievements in music would be minimal or non-existent rendering them reluctant to teach music.Plummeridge (1991) argues that music should be handled only by musicians. At the other extreme, Mills (1989) asserts that music is for everyone and advocates that all primary teachers have the potential to teach music. Such views of Plummeridge (1991) are likely to perpetuate the low status of music in schools and lead to the notion that only music specialists are capable of teaching music and so provide class teachers with an excuse to avoid teaching music which I disagree. Nonetheless, teacher education has an opportunity to break this cycle by acknowledging class teachers to understand the effects of the nurture in musical achievement, and make them believe in their own and the children's musical potential in classrooms (Mills, 1995).

\section{Instructional Materials in Music and Dance}

Instructional materials are materials used in support of instruction of a subject by teachers. These materials include, curriculum guides, books, audiovisual (television, video and audio devices), programmed approaches (computer assisted programmes), Miniature musical instruments like the xylophone, keyboard, guitar, drums, bells, cymbals, castanets and so on. Primary pupil vocal reproductions of relatively short song phrases are improved by the repeated viewing of a participatory instructional music television programmes. The frequency of students' echo-singing and the accuracy of their echo-singing responses are increased after viewing an instructional music programme. Although television instructional programmes have all this advantages there is an absence of accompanying evidence to document increases in music achievements among children as a result of viewing those videos or television programmes (Feierabend, Saunders and Barbra, 2002).

Computer assisted techniques have the potential to take over a lot of the work of the music teacher. They may be most appropriate for the teaching of lower level skills; freedom from the chores of the routine exercises ought to enable the teacher to spend more time on those parts of the job that fully utilize his/her advanced skills and experience. Computer assisted techniques provide privacy and individual attention; immediate feedback of results is available at any time and students' progress is cumulatively recorded over a course of study (Hargreaves, 1986). Instructional materials like books and miniature instruments are primary 
source of materials mostly used for instruction by teachers. With regards to all the advantages of these instructional materials, music teachers should note that these techniques are essentially tools to assist them and they cannot in themselves determine in broader perspective the objectives of music education. So as a primary teacher with some or most of these instructional materials at your disposal, teachers are to use them to help children make meaning out of these instructional materials with the appropriate methods to help children attain holistic music education. Evans (1975) concludes that, rather than wait for foreign equipment, she suggests, there is material here - all around us - in the form of natural material resources and local cultural resources. Evans went on to add that, all we have to do is reach out and take what we wish from the rich heritage. There are sufficient instructional materials in our school environment for teachers to use but they do not use these local resources.

\section{Importance of teaching Music, Dance and Drama in Primary Schools.}

It is not for a fun putting the performing arts in the school curriculum, the planners of this curriculum knows the benefits pupils derive from studying the subject hence its inclusion in the school curriculum. According to Jensen (2002:20) "Music can charge and energize our brain. When music harmonizes with our own rhythms, we feel energized by it". Page (1995:9) maintains "music strengthens attention spans, aids memory, and provides creative outlets. Music is good for us - it's good for our brains, our bodies, and our spirits". Most children respond to music. If used carefully and appropriately, it can be a positive way to assist children to develop their potential in a number of growth areas. And to achieve all these teachers should be trained to help pupils to benefit from the Music and Dance class.

Swanson (1969:12) states "they (children) can find ways to express their joy or sadness, their feelings of aggression or loneliness".School music programmers have activities which involve listening to music, and often the response is overt, perhaps singing, moving or accompanying with instruments. However, children also need to be given many opportunities to 'listen for the sake of listening', as it is through listening that they become familiar with and learn to appreciate, various types of music including the music of different cultures. Swanson (1969:13) maintains "Listening is basic to all of music-making. As a child sings and plays instruments, he listens. As he interprets music through bodily movement, he listens".McGreevy-Nichols and Scheff (1995) state "dance is movement created and executed to satisfy a need. It can be stylized, done to music or not, tell a story or not, create images, use space, define moods, create and channel energy" (p. v). Loeffler (2003:1) expands this description "Creative movement and dance is an enjoyable way for young children to develop their physical skills, channel their energy, stimulate their imagination and promote their creativity. Creative dance involves using body actions to communicate an image (the wind), an idea (a journey) or a feeling (strength)". Cone and Cone (2005:12) maintain "Dance provides children with the means to express and communicate what they really feel and know about themselves and the world.... Socially, children enjoy interacting with others through movement. They laugh and talk with each other while sharing an experience that is fun and personally rewarding".

Dance is a medium through which children can develop co-operative skills. Cone and Cone (2005:12) believe that "While dancing in a small group, children assume various leadership roles, learn to share ideas, practice moving together, and develop a group identity" They can work with each other and within a team situation.Today children live in a society and a culture that is so busy that it does not come together as their forefathers did, therefore the school has a certain responsibility to help children to learn the cultural and community concepts of dance and its role in society today.Burton (1987:1) asserts that "Drama is a way of exploring and understanding the world. In common with language arts, it teaches communication skills and the use of language and the imagination. Like physical education, it involves physical development and coordination, and it shares with art an interest in creativity and self-expression". O'Toole and Dunn (2002:3) maintain that "Drama is about exploring - discovering and creating - and about performing. Principally, especially in the primary years, it is about creating models - models of behaviour and action that can be practiced and performed safely". There are many reasons for children to participate in drama in the early years of their education. Young children explore their world and new concepts throughplay, and then they need to be given opportunities in a relatively controlled environment to do so. The naturalness, delight and ingenuousness of young children's play can betransferred into the formal learning environment of the classroom through drama. 


\section{Creative Arts (Music and Dance) in the Primary Schools}

Music and Dance is one of the compulsory school subjects in the curriculum for all children regardless of social, ethnic and cultural origins, gender. It is a requirement for all children to receive a general music education based on the curriculum. Several opinions can be put forward for the inclusion of music in a curriculum. To start with, Music has a potentially important value in people's cognitive and aesthetic attitude development, and in cultivating their feelings through creative thoughts and actions (Gulbenkian, 1982). Again, Music contributes to a child's education by developing the fullvariety of human intelligence (Gardner, 1985). Added to that, music is seen as a specific form of knowledge in a system in which the acquisition of knowledge is a major aim of general education (Ucan, 1997). Also, evidence shows that Music can improve children's overall academic performance (Music Education Council et al, 1998). Finally, music experience can be accepted as valuable in itself, and not merely as a means to attain some other educational goals. The society's beliefs about music and musical ability bring to bear an influence on the curriculum. Since music is part of the life style, it is part of the school curriculum. Curriculum can be considered as a bridge, between the needs of society for music, and the needs of schools to implement the music education for the expected outcomes. Therefore, curriculum development is crucial in order to establish a good balance between culture in the society and culture in the schools. However, who decides what to teach in music is a vital question as decisions on music teaching can be under the control of groups of people whose values beliefs and truths are written in the curriculum and which may create tensions between them and teachers, since teachers are responsible for implementing these proposed ideas in the curriculum whether they are practical or not. Teachers in schools therefore cannot be underrated.

Ghana has a wealth of musical traditions and Music and Dance is an integral part of life in many societies in Ghana. However, in 1966 the music programmes in Ghana like in many African countries did not resonate with societal needs. Nketia said: Since music is practised as an integral part of social life, there is a danger that musical activities in the classroom, an artificially created musical situation, may be unrelated to the experience in society (Nketia 1966:231).Nketia advocated for a review of the curriculum in Africa with knowledge of the psychology of African music (1966:240). By 1982, various schools started offering indigenous Ghanaian music as part of their educational programme; however, it was based on the Western approach as a result of the missionary educational foundations that prevail in the country. Akrofi pointed out that the instructional approach to school music in Ghana has been that of transmission of specific information which is as a result of over-reliance on Western classical music and the British examination syllabuses (Akrofi as quoted by Oerhle, 1991).

\section{The Role of the Music Teacher in Primary Schools}

Ghanaian music is presented to Ghanaian children as an imported material. On the other hand, the researcher adds that it is not just the imitation of the Western approach by the Ghanaian music teacher that is the problem, but that the music teacher is not grounded in his or her own traditional musical culture which is a big setback in his or her capacity. First and foremost, the Music and Dance teacher should understand what he or she is expected to impart to the learners. Very often these actions can and do, in fact, separate the music from the cultural backgrounds of pupils not deliberately but because the teachers are not traditionally equipped in music. Herbst (2007) opines that many teachers from this generation have not taken part in traditional musical performance; therefore, the general class teacher should continue to use music in its supportive function while a specially trained music teacher should take care of the music instruction that has indigenous music at its core. The researcher takes an exception of Herbst argument because specially trained teachers come with a cost. My suggestion is that Colleges of Education should be resources to trained generalist teachers to teach Music and Dance in their classrooms.

The music educator is there to structure experiences that lead to more enhanced, more creative musical thinking, build a vocabulary that pupils have no words to describe, and build a fluency in musical reasoning of an understanding of the musical narrations that have built the range of the musical experiences in relation to their culture. Nketia (1999) comments that the teacher must provide children with growing up experience, for teaching traditional music in the classroom can be one of the ways of ensuring continuity of cultural transmission.Herbst (2007), states that in content and methodology in primary level more weight should be given to guidance than instruction. The music educator is the mediator in a democratic transaction of music knowledge (which is a powerful learning process), not an autocrat. This is a factual statement because 
traditional music is a practical subject knowing how far it has travelled and passed on from generation to generation yet it lives. Even though rapid changes in our social, religious, economic and even political lives are causing it to lose values in our traditional music in society. The music educator also seeks to develop musical self-esteem in children and feel of satisfaction when they achieve something worthwhile. It is on this note that the researcher agrees with Mills, (1998) who states that, if self-esteem is good for children, then it seems likely that it is good for the teacher teaching music. The role of the music educator is as important as the subject itself in the life of the pupils, because the fundamentals of Music and Dance will not be effectively rooted if the educator's role is under estimated. So important is the role of the educator in the educational process that quality educational product is measured against the educators' efficiency. To live up to fulfilling that role, the music educator needs to increase the capacity to meet the challenges associated with contemporary educational processes. In this regard, the researcher agrees with Tewiah (1994) cited in Flolu and Amuah (2003). She opines that every person, whether literate or illiterate can provide information to others but that is not teaching. She continues that teaching is an art which requires skills and specific knowledge and that good teacher education is important.

\section{Music Education Programmes in the Colleges of Education}

Music education pursued in the training colleges established by the missionaries was designed to satisfy the needs of the church. Students were trained specifically to sing hymns used by the denomination that established the colleges and students who demonstrated interest in the study of organ or wanted to lead church choir were given extra tuition in music reading and organ playing (Akrofi, 1989). Students were taught rudiments and theory of Western music and prepared them to take British external examination in music particularly, the Associated Board of Royal Schools of Music Examinations (ABRSM) (Flolu, and Amuah, 2003).Music in schools was for the preparation for church activities and no aspect of traditional music was considered suitable for use in church worship and school, and this still remain the root cause for the conflict between Western music and African music in Ghanaian schools of today. Some orthodox churches established institutions and the first teacher training college was Basel mission in AkropongAkwapim, followed by Methodist Grammar school at Cape Coast, Anglican, Catholic, and Bremen missions followed suit. The purpose of these institutions was to train teachers, catechists and church workers, so the curriculum was designed to suit these needs, but more so they were intensive training in the art of hymn, singing and conducting in order to lead church choir or singing groups when they go out. Eventually the various hymn books for the institutions becomes textbook for teacher training colleges (cited Akrofi 1981) and this has resulted in producing renowned musicians of our time namely Nketia, Nayo, Dossoo, Amissah among others.

The post-independence era saw a rapid expansion in the educational system in Ghana. Not only did the Accelerated Development Plan of 1951 usher in a proliferation of training College in Ghana, but also the development of the new curriculum to meet the needs and aspirations of the emerging new nation (Flolu and Amuah,2003). However, the missionaries influence in the area of music education in the training college was so strong that there was no significant change in the structure of music teaching and learning in the colleges. Amuah, (1988) noted that, the focus on music education was still on the singing of English hymns and patriotic songs. The music curriculum in the training colleges was unresponsive to the cultural reawaking. It was cosmetic additions of African indigenous musical practices made in the curriculum of both primary and teacher training colleges music programmes (Flolu and Amuah, 2003). Nketia observes that African music was treated and continues to be treated "as appendage to an existing Western curriculum". It is just paying lip service by curriculum developers that they have added African music to music at the training college syllabus without making a follow-up to see whether the intended purpose of that is yielding result or not.

\section{Relevance and Nature of the Music Courses}

One of the main assumptions of teacher education courses is that students will use the music course content when they become classroom teachers. If the instructors and their personal views are the main source of decisions about music course content, it is important that they consider what type of knowledge or skills would be most useful for student teachers. The key issue is that if student teachers can understand the function of the music course content in their teaching, they may become more positive and more enthusiastic teachers in their classrooms.Bresler (1993) points out those teachers who lack a formal musical background 
and continued practice develop a reluctance to teach music and have low confidence. They perceived music instruction as requiring special skills, special language, and pedagogical practices that they did not have. Furthermore, Gamble (1988) has shown that student teachers who felt that they were not able to sing or were tone deaf became unbearably anxious when asked to perform simple tasks on classroom instruments. Thus, if Creative Arts (Music and Dance) courses continue to be theory in Colleges without practical, it would not help develop positive attitudes on the part of teachers to teach Music and Dance in classrooms.

\section{Music Teacher preparation in Colleges of Education}

During data collection in the Nanumba North District-Bimbilla for the study, three (3) schools were chosen. These schools were E.P Demonstration Primary school (A) - Bimbilla East Circuit, Our Lady of Peace Primary school (B) - Bimbilla West Circuit and Kpabi D /A Primary School (C) - Bimbilla Rural Circuit. Thus going through the classrooms, Creative Arts could be seen boldly on the timetable and knowing that Music and Dance is part of Creative Arts, I was satisfied with getting access to more data for my study. However, when my intention was made known to the teachers, there were mixed reaction from the classroom teachers. Teacher preparation in the Colleges of Education is very important in the training of teachers because this is where they are exposed to contents and the techniques of teaching. Their preparation serves teachers as the foundation on which everything about a school revolves. Skills and knowledge are acquired at the Colleges of Education to help teachers teach effectively and efficiently. Good teacher preparation would provide quality teachers.

Respondents were asked to give an impression of their Music and Dance teacher preparation in their various Colleges of Education each attended and also tell whether what was studied was related to what goes on in their music and dance classrooms. Some of their responses were; "I learnt Music in the first year that was all and no relationship between them", "I learnt Music content in the first year however I can say there is no bearing in what is going on at colleges and primary school in terms of Music and Dance", "there is a relationship because Music only entertains the children and make them express themselves", those were the responses from school A. In school B they have this to say: "yes I did music and dance and there is a relationship because of tones or note values", "it was only first year I did music and dance and there is no relationship because I find it very difficult to teach topics from the Creative Arts syllabus (Music and Dance)". "There is no relationship between primary and college music and dance syllabus because of the contents", "I cannot tell if there is a relationship because I did music in first year", "although I did some music at college however I cannot tell if there is any relationship or not", those were some views expressed by respondents from school C. Grossman, Wilson and Shulman (1989) opine that teachers need to understand their subject in ways that promote learning. Knowledge in one's subject is highly important for effective teaching and confidence in dealing with children's questions and responses (Aubrey, 1993).

Table 1: Course Outline for First Year Second Semester of the Performing Arts in Colleges of Education (Credit Hour: One (1)

\begin{tabular}{|l|l|}
\hline \multicolumn{1}{|c|}{ Topics } & \multicolumn{1}{c|}{ Sub - Topics } \\
\hline $\begin{array}{l}\text { Elements of music. } \\
\text { Rhythm and rhythmic patterns }\end{array}$ & $\begin{array}{l}\text { Note values and their respective rests } \\
\text { Accent and times, simple time signature, } \\
\text { Treble and Bass staves with their respective letter names. } \\
\text { Volume and tempo }\end{array}$ \\
Dynamics & Cantor and chorus \\
Form and structure & Dynamics, forms, balance, space, energy \\
Elements of dance & Labanotation- movement for direction and levels. \\
Movement notation & Membranophones,idiophonesChordophones, Aerophones. \\
\hline
\end{tabular}




\begin{tabular}{l|l|}
\hline Classification of African instruments & $\begin{array}{l}\text { Art music composer, popular music composer and traditional } \\
\text { music composer. One from each. } \\
\text { Some performing arts personalities } \\
\text { Three (3) of any traditional dance ensembles } \\
\text { in Ghana. }\end{array}$ \\
$\begin{array}{l}\text { Some Traditional Dance Ensembles } \\
\text { in Ghana }\end{array}$ & $\begin{array}{l}\text { and religious roles } \\
\text { The role of performing arts in }\end{array}$ \\
Ghana.
\end{tabular}

Table 2: Topics of Music and Dance in a Creative Arts Syllabus Primary One (1) First Term

\begin{tabular}{|l|l|}
\hline \multicolumn{1}{|c|}{ Unit } & \multicolumn{1}{c|}{ Contents/Topics } \\
\hline Composition(improvisation) & Movement exploration \\
\hline Listening and observing & Listening and observing artistic performance. \\
\hline Performance & Singing/Dancing/ Musical Games e.g. stone passing games \\
\hline
\end{tabular}

\section{Second Term}

\begin{tabular}{|l|l|}
\hline \multicolumn{1}{|c|}{ Unit } & \multicolumn{1}{c|}{ Contents/Topics } \\
\hline Composition(improvisation) & Sound exploration and Comparing sounds \\
\hline Listening and observing & Observing costumes for various dances, drama and music \\
\hline Performance & Dramatising scenes through singing \\
& Drumming playing simple rhythm from a local ensemble. \\
\hline
\end{tabular}

\section{Third Term}

\begin{tabular}{|l|l|}
\hline \multicolumn{1}{|c|}{ Unit } & \multicolumn{1}{c|}{ Contents/Topics } \\
\hline Composition(improvisation) & Creating rhythm to accompany known songs. \\
\hline Listening and observing & Creating sound games \\
\hline $\begin{array}{l}\text { Performance (Playing) } \\
\text { Dancing }\end{array}$ & $\begin{array}{l}\text { Playing the time-line of an ensemble.Instruments in set up in local } \\
\text { ensemble. } \\
\text { Performing basic movement patterns. } \\
\text { Dancing Skills;leg and arm movements. }\end{array}$ \\
\hline
\end{tabular}

Table 3: Topics of Music and Dance in a Creative Arts syllabus,primary five

\begin{tabular}{|l|l|}
\hline \multicolumn{1}{|c|}{ Unit } & \multicolumn{1}{c|}{ Contents/Topics } \\
\hline Composition(improvisation) & Create melodic patterns in response to a given phrase \\
\hline Listening and observing & Creating, performing and analyzing variations in dance patterns. \\
\hline Performance & Singing the National Pledge song and discussing values identified. \\
\hline
\end{tabular}

\section{Second Term}

\begin{tabular}{|l|l|}
\hline \multicolumn{1}{|c|}{ Unit } & \multicolumn{1}{c|}{ Contents/Topics } \\
\hline $\begin{array}{l}\text { Composition(original } \\
\text { works) }\end{array}$ & Compose simple rhythmic patterns using the conventional symbols. \\
\hline
\end{tabular}




\begin{tabular}{|l|l|}
\hline $\begin{array}{l}\text { Listening and } \\
\text { observing }\end{array}$ & Analyze variations in dance patterns. \\
\hline Performance & Sing simple and familiar songs accompanying them with dramatic actions. \\
\hline
\end{tabular}

\section{Third Term}

\begin{tabular}{|l|l|}
\hline \multicolumn{1}{|c|}{ Unit } & \multicolumn{1}{c|}{ Contents/Topics } \\
\hline Composition(improvisation) & Create music in three part form. \\
\hline Listening and observing & Identify individual instruments within a performance \\
\hline Performance & Create a story and perform them. \\
\hline
\end{tabular}

Creative Arts (Music and Dance) syllabus is one of the subjects taught in Ghanaian primary schools. Music and Dance contents in the Creative Arts have been divided into three (3) units or components namely composition (improvisation), Listening and observation and performance. Under each unit, there are a number of topics that are lined up for teachers to teach. On the part of Colleges of Education, there is a course outline for performing Arts (Music and Dance) drawn by University of Cape Coast in which a number of topics have been spelt out for teacher trainees to be taken through to prepare student teachers to teach effectively if they become teachers.

In Colleges, the trainees are supposed to study the following topics: elements of music, pitch notation, elements of dance, Laban Notation, classification of African instruments. This is to prepare the trainees for teaching Music and Dance in the primary school. On the other hand, in Creative Arts (Music and Dance) syllabus the following topics are studied; movement and sound exploration, dramatizing scenes through singing, playing simple rhythm and time line from a local ensemble, creating rhythm to accompany known songs, compose a melodic pattern in response to a given phrase, analyze variation in a dance. However, comparing the syllabus for primary one (1) and five (5) with the above outline for colleges, one can infer some topics in the colleges could better be understood, for example (elements of music) if they are clearly grouped under the three components thus: performance, listening and observation and composition to guide the trainee in relating well the knowledge acquired in music and dance to the pupils. Without this you can also observe a clear gap created between the content of the colleges and the primary schools thus there is little correlation between the topics because the primary is purely practical than the college one.

In the Creative Arts syllabus, the topics were about creating, composing, playing, dramatizing, analyzing, making movement and singing but when you take a critical look at the topics in Colleges is solely theory which in the researchers' view is not enough to equip the trainee to be able to teach Creative Arts (Music and Dance) in the primary school. In looking at the college Music and Dance syllabus and Creative Arts (Music and Dance) syllabus, one would expect that the topics outlined in the Music and Dance syllabus for College of Education should have a relationship or similarities with what pertains in the Creative Arts (Music and Dance) syllabus. In other words, the topics in the course outlined for Music and Dance for Colleges of Education should have some influence or prepare student teachers if not in all the topics but for a few of them to help student teachers teach effectively. It could be deduced that the topics in both syllabuses are different. There is no relationship between the topics and it would be extremely difficult for any teacher trainees to be able to teach most topics in the Creative Arts (Music and Dance) effectively. However, in the primary school Music and Dance is all about performing traditional ensemble but that of the colleges is all based on theory.

Preparing teachers at Colleges of Education in Music and Dance have been going through some kind of challenges. Bodegraven (1946) opines that courses in music education have been poorly taught more often than they have been well taught. Bodegraven further affirmed that four years is a short time in whichto 
prepare a person for a career in music education. This brilliant statement above fits our conditionhere in Ghana in that Ghana's Colleges of Education Music and Dance is taught in two (2) semestersout of six (6) in three years that a student has to spend in the college. So if Bodegraven suggested that four years was short to prepare person to teach Music then what will then happen to person who will be trained for four (4) to eight (8) mouths to teach Creative Arts (Music and Dance) in the primary schools. Meanwhile, it is obligatory for all Colleges of Education students to take Music and Dance in the second semester of the first year, in what may be described as the content, the student is taught elements of music, elements of Dance andDrama, Fundamentals of Laban Notation, Traditional ensembles, music and dance in Ghana andbiographies of some Ghanaians in the arts.

In the second year, first semester, whether the student is adequately grounded in the course ornot those interested, and having chosen it as an elective course would then be taken through someaspects of methodology to prepare them as Music and Dance teachers. If student teachers did not choose the subject (Music and Dance) the students go out in the third year (teaching practice) with an incomplete exposure of teaching Creative Arts (Music and Dance). Without a solid foundation in acquiring any techniques in teaching and learning of Music and Dance at Colleges, teachers could not be in any better position to implement or interpret the Creative Arts (Music and Dance) syllabus for pupils to understand. This would lead to sidelining of Music and Dance in schools because teachers do not have any skills and knowledge to practice teaching.

Participants were asked during the interview to give their impression about the Music and Dance teacher preparation in the Colleges of Education they attended. It was found out that what the teacher trainees studied in their respective Colleges of Education in terms of music content was not directly related to what goes on in the classrooms because it was found out that the Creative Arts syllabus (Music and Dance) was full of music practical lessons which is in contrast to the content in Music and Dance at the Colleges of education. This therefore dampened the confidence of the teachers in the teaching of Music and Dance thereby limiting their creativity in the delivery of their lessons.Music pedagogy includes structures and principles for the planning and analysis of music teaching,including planning, execution, evaluation models and concepts such as objectives, content, methodsand assessment (Kertz-Welzel, 2004). Respondents were not exposed to all these academic aspects of Music methods but now teaching Creative Arts (Music and Dance).Teachers' low perception of their own competence and confidence as music educators and in music teaching were offset by their enjoying, and valuing music and music education less (Gifford, 1993). Gifford also points out that pre-service teachers see their ability to teach music largely in terms of their personal musical skills; and that a traditional oriented and developmental skills-based music education course may not be the most appropriate way of training primary teachers, noting that 'music education programmes currently operating do little to enhance confidence, skills, and value. Grossman, Wilson and Shulman (1989) opine that teachers need to understand their subject in ways that promote learning. Knowledge in one's subject is highly important for effective teaching and confidence in dealing with children's questions and responses (Aubrey, 1993).

\section{Methodology of Music and Dance in Colleges of Education}

The preparation of teachers and other school personnel is critical to all other professions and to communities and the nation. The professional educator plays an essential role in student learning. Colleges of Education are mandated to produce prepared, able, and responsive professional teachers to teach and support diverse learners in any subjects including Creative Arts (Music and Dance) in the primary schools. The quality of music education in every society is largely determined by the quality of its teachers. On the other hand, the quality of teachers is determined by the level of their subject matter mastery and how they pass on that subject matter to their learners, among many other factors. Teachers' ability to teach depends on how the Colleges of Education prepare them for teaching. The Colleges of Education are mandated to provide teachers with intellectual and professional background through the study of academic content, professional and pedagogical studies, and create the opportunity for student teachers to practise teaching. In many contexts, it is the foundation that informs teacher's practice the most.

The respondents were asked if they have studied methodology in Music and Danceat their various Colleges of Education. These are the responses from school A; "I did not do methodology in music but in sewing", "I 
have not done music in college", "I have not done music because I like drawing". When it was the turn of school B respondents had these to say, "Yes I studied music at college", a follow-up question to find out if it was in music content or methodology, he said "it was in music content", "I learnt methodology in religious and moral education at college but not in music". In school $\mathrm{C}$ their responses were not different from the respondents from other schools, "I did music and dance in first year but in second year I chose vocational skill because I like drawing". "I did methodology in catering not in music". "I chose pre vocational skills because we were allowed to select a subject to do as an elective, so I went in for pre vocational skills but not Music". It should be noted that none of the respondents of the study did any methodology in Music and Dance at their various Colleges of Education and it is the same respondents who are now managers in their classrooms without having the necessary pedagogical skills and knowledge; the results are what we are seeing today in our schools. The ultimate aim of a teacher is to teach every subject when he or she completes his or her programme of studies which will propel them to have skills and knowledge to be able to discharge their duties as teachers. Before completing a programme of studies in any College of Education in Ghana, student-teachers ought to be taken through the contents of that subject and taken them through the skills and knowledge of how to teach that subjects. However, in the case of Music and Dance the respondents from school A, B and C did not do any methodology in Music and Dance at their various Colleges of Education thereby making them handicapped in implementing the Creative Arts syllabus (Music and Dance).

\section{Teaching Practice in Music and Dance}

Teaching practice is an essential component in all Colleges of Education programmes. During teaching practice, student teachers are placed under the guidance of qualified professional (mentors and tutors) who introduce them to teaching and its routines in order to develop in them the required professional skills and competencies, and positive attitude towards the teaching profession. Teaching practice also provide the right environment for student teachers to familiarize themselves with all the processes of the school setting, and to observe example of good practice. Student-teachers will be competent and capable of providing quality music education for pupils in the primary schools across Ghana. Teacher Education involves the policies and procedures designed to equip teachers with the knowledge and skills they require to teach effectively. Teaching practice is an integral part in teacher education because it allows student-teachers to translate theories learnt into practice. Effective preparation of student-teachers in practical subjects like music and dance could help them teach efficiently as a result, promoting learners' skills in particular; creative and practical skills support healthy development. Thus, teaching practice is perceived by educators as a training requirement for teachers.

Marais and Meier (2004, p. 221) note that "the term teaching practice represents the range of experiences to which student teachers are exposed when they work in classrooms and schools." It is a fundamental element of teacher training and refers to students' placements to schools to practice lesson planning, classroom organization and most importantly classroom teaching. It is an essential part of effective professional training. Kiggundu and Nayimuli $(2009$, p. 347) view it as "... a form of work-integrated learning that is described as a period of time when students are working in the relevant industry to receive specific inservice training in order to apply theory in practice". Thus, it is time spent by student-teachers in schools to gain practical teaching experience.

However, despite its importance, teaching practice could be very challenging and hence demoralizing and sometimes very frightening experience if students are not well prepared. It is worth noting that students' experiences during teaching practice can influence their perception and attitudes towards the teaching of the subjects (Music and Dance) they are trained to teach and their teaching profession as a whole. During interactions with participants of the study, a question was asked about whether music and dance was taught during their teaching practice and almost all the answers given by the respondents from school $\mathrm{A}$ and $\mathrm{C}$ were the same. This was what they have to say: school A: "we were not allowed to teach Music and Dance during teaching practice" and when asked why he said "I do not know", "I did on campus teaching practice in some subjects but not in Music", "we were allowed to teach important subjects like Mathematics and English but not in Music and Dance but I like teaching it because I like drawing". In proceeding enquiry to find out more about the same question in school B, the following findings were provided; "we were not assigned to teach any other subjects except Mathematics" and so on and she went on to say that "Music and Dance is a difficult subject", "I taught Creative Arts during teaching practice and the aspect was pre-vocational skill 
because the material received from the head teacher was based on drawing and in that book there was nothing like music". Preparing student-teachers in Colleges of Education to teach Music at the primary school, there is the need to teach concepts in the subjects they are trained for, in order for them to provide quality music education to learners. It is during teaching practice that student-teachers should practice what they learnt in classrooms to prepare for their teaching profession.

\section{Relationship of Music and Dance in Colleges of Education on Primary Schools}

A question was posed to the respondents on relationship of Music and Dance at the Colleges on the primary schools. The respondents confirmed that teaching and learning of Music and Dance at Colleges of Education ought to have a relationship with the primary schools Creative Arts (Music and Dance) syllabus in terms of the contents and as well as the methodology. This includes learning the skills and the pedagogical knowledge of teaching Music and Dance. These were some of the views expressed by the respondents in school A, one had this to say: "she did not think there is a relationship between Music in Colleges of Education and the primary school Music and Dance because she does not seem to know how the Creative Arts syllabus is structured". She went further to state that "she does not understand the Creative Arts syllabus". To her "there is no relationship between them because there are differences in the contents". For example, "at the College I did no music practical lesson but the Creative Arts syllabus (Music and Dance) is full of practical lessons". These are the similar concerns raised by the respondents in that particular school.

In school B, one of the respondents also said "there is a relationship in college music and that of the primary because of the tone, tone, and semitone". He further went on to state that "learning of Music and Dance at both college and the primary school was relevant". Asked to explain its relevance, he said "music has prepared me well-I thought Music and Dance is only about dancing but it has a lot of things in it. For example, tones (how high or low) learnt in the college". Another one also said "the subject has some relationships because it only entertains the pupils and make them express themselves well".

An interesting response was given by one of the respondents when the researcher asked the same question in school C, she said, "I can say that there is no relationship between them because music topics taught at Colleges of Education are different from what is going on in the primary school","I have not been teaching because it is not on the timetable. Hence I cannot identify any differences or relationships". Almost all the participants seem not to agree on whether there is a relationship or any influence. Dzorkpey (2000) observed that attention should be paid to the training of pre-service Music Education because no amount of planning for a music curriculum and classroom material can be of any value if the teacher has no knowledge of the subject itself and how to teach it. If the authorities are only interested in formulating music curriculum to the neglect of training the teacher who is the implementer, then we must start revising our notes. The Colleges of Education ought to take into account the issue of relevance in order for the curriculum to provoke the potential of student teachers to teach their learners. This will also enhance the potential of teachers to solve their own problems through observational and analytical capacities. (Masoga 2002) asserts that there is a need to find a correlation between what is learnt at school and its ability to transform society into a better place. Otherwise the time spent at school will be wasted. There has to be a direct relationship between what is learnt at school and cultural, social, community and economic development. (Kyeyune 2002) states that there is a need to review curricula, ascertain relevance and deal with gaps that must be filled in order to answer the call for education to serve current needs.

Results from the data collected from the three selected schools A, B and C indicated that the respondents do not find any relationship between Music Education at Colleges of Education and the primary school Creative Arts (Music and Dance) syllabus. Cutietta (2007) contends that content in the music syllabus must answer to the needs and wants of students during and eventually after their training. Cutietta (2007) further argues that the content should be that which will make students to develop the knowledge and skills that they will use to teach in schools so that people can see the importance of Music Education and stop to question its relevance to prevent it from being marginalized. Mubita et al. (2005) contribute to this notion by stating that the content in the music syllabus must reflect students' out-of-school experiences so that there is no gap between what goes on at home and the school.Deducing from the above, it could be inferred that both tutors and student-teachers in the Colleges of Education were not satisfactorily utilizing the music component so as to develop relevant musical skills for the purpose of their teaching Creative Arts (Music 
and Dance) in primary schools. The main objective of the Colleges of Education is to prepare teachers to be able to teach all subjects in primary schools inclusive of Music Education. My observation is that teachers are not doing same according to the purpose of training teachers to teach Creative Arts (Music and Dance) in the various primary schools.

With regards to the above discussion, Chanunkha (2005) argues that when students are not well prepared, their teaching is likely to be compromised, and consequently lead to the subject being marginalized. This seems to imply that once students are sufficiently prepared in Music Education the subject will no longer be marginalized. Added to that, well trained teachers will teach Music and Dance in primary schools properly to the expectations of the people and the country as a whole. For Music and Dance syllabus used at the Colleges of Education answer the questions on the successful training of student-teachers in Music education, revising the Music and Dance syllabus would bea requirement. This is important because Music and Dance syllabus at the college will help in exposing student teachers to the music which they may find easy to learn and understand since it is familiar to the learners. This will go a long way in helping or influencing teachers to successfully implement the Creative Arts curriculum (Music and Dance). Music and Dance teaching is experiencing a problem of relevance. The content of the Creative Arts syllabus (Music and Dance) addresses the indigenous music of some major ethnic groups in Ghana that learner needs but the teachers lack the experience and the exposure to teach the pupils. Also, teachers do not acquire sufficient skills to teach all the aspects of Music education. In view of these and other irregularities, teachers in different schools teach different content depending on their respective strengths. The duration and content in classrooms differ from school to school, and the difference hinders the enforcement and consolidation of the syllabus amongst diverse schools.

\section{Traditional music in Colleges of Education and primary schools}

Indigenous music requires the total involvement of the individual performers to express themselves through the instruments played, the songs sung and the dances in which they are involved. According to Abrokwaa (1999), the most important aspect of the curriculum is improvisation since it forms the heart of indigenous African music. It permits the player or singer to express with boundless freedom and to explore his or her inner musical sounds and abilities. Unlike the frequently changing Western curriculum, the indigenous curriculum is founded on social loyalty that focuses on the acquisition of skills and cultural information which will later enable the performer to fit into his or her society. According to Blacking (2000), indigenous African music education aims at giving the children and young people of the community socio-cultural knowledge and skills in a holistic way involving real life experiences. Learners acquire this in developmental stages from adults. Where adults failed to do their jobs well, then the mantle will fall on Music and Dance teachers in the primary schools to be in the position to teach their pupils or learners about the music and dance practised by their communities. Blacking (2000) continues that, music can express social attitudes and cognitive processes, but it is useful and effective only when it is heard by the prepared and receptive ears of the people who have shared, or can share in some way, the cultural and individual experiences of its creators.

Interacting with respondents of the study, a question was posed as to whether they were taught traditional music at colleges and to find out if the respondents were teaching it in their schools. A teacher from school A indicated that; "I do not teach any traditional ensemble in my school", another one mentioned that "although there are a lot of traditional music performances in my community but I do not take part in them", one also said"there was nothing about traditional ensemble or activities in the college except during the celebration of School Representative Council week where opportunity was given to the ethnic groups on campus to perform their various traditional dances", "I do not teach traditional music in primary school because I was not taught at College".

In school B, one of the respondents has this to say; "there was no traditional dance at College because the music tutor never taught us even one", "I have not been teaching it because I have no ideas in teaching it" "I do not teach but always invite a resource person from town to help teach some traditional dance to pupils. He went on to say that, when they are invited by the teacher to teach traditional music they do not honour the invitation sometimes and when the resource persons do come, teachers are compelled to motivate them financially". It was similar answers given by the respondents in school $\mathrm{C}$ and some of the responses were; "I 
do not know the dances in the syllabus so I do not teach them at all", "I am a Dagomba by tribe, how could they expect me to teach a dance in Akan tribe". Asked whether if he could teach Damba, his answer was "no". "I have not participated in any of the traditional dances in my school, let alone teaching it".Nzewi, (2003) points out that indigenous music learning has a philosophy and a systematic procedure of teaching or transmission. He explains traditional music education as being holistic, enabling the learner to become a competent composer, performer, and critic. It is a true paraxial form of education based on two principles, the first of which being, that the learner learns through experience. As Tracey and Uzoigwe (2003) explain that the process of learning in traditional Africa is one of long exposure, immersion in the totality of its expression and relationships with life, values and morality.Tracey (1986) describes the learning of indigenous music as one of co-operation. He highlights the fact that meaning is closely related to participation, African music representing one form of co-operation.

For Music Education to be effective, Reimer (1989) suggests that all music used in the teaching process should offer many opportunities for the students to become fully involved in exploration and discovery. Students should be given every opportunity to compose, create, and perform music while the teachers facilitate and guide the students without imposing their ideas on them. Reimer (1989) also points out that when students are involved in creating arts, they must be involved in making artistic decisions. Teachers who work on the 'Just do as I say' principle ensure the element of creativity is removed and students remain only partially involved with the art.Nzewi (2001) argues that, the African child's basic formal music education should rely on the indigenous African models and resources for the theoretical and material content. The method should be strong in practical music experiencing, which should make clear the theoretical explanation. The way to approach music learning should be through African folklore and shouldstart withthe music of the child's immediate social and cultural locality. As the child gets older, other music cultures and practices may be included. Teachers teaching Music and Dance in the primary schools ought to be conversant with the music and dance performed in the locality of where the school is located to enable the teacher to build on it while teaching.

The music of Africa is clearly diverse in the way that it sounds from area to area and how it is used within society (Rocheleau, 2009).As "each culture has its way of passing on the rules of music-making" (Nettle, 1998, p.28), it is important to know what these are; and future Music and Dance teachers need to find out what they are before teaching indigenous Music and Dance from other cultures. Pupils' engagement in traditional music-making can demonstrate that it is possible to pass on knowledge, skills and understanding of music and dance in primary schools. It is necessary to prepare Music and Dance teacher students to be culturally responsive, because in their future classrooms, these students will teach children from various parts of the country with diverse range of languages, ethnicities, cultures and traditions. Teachers have a responsibility to prepare their future students as universal citizens respectingall cultures.African music permeates every aspect of life and that it is interactive, participatory and communicative (Opondo, 2000). Music may provide a rich pathway for strengthening the foundations of tolerance, reducingdiscrimination and violence, and learning to live together (UNESCO 2014a).UNESCO (2014a) again points out that it is especially important to reach out to children and young people during their formative years, notably through educational materials and curricula, to teach about tolerance and understanding of all people. All these things can be achieved by taking children through indigenous music by their Music and Dance teachers in primary school. Unfortunately, the findings from the selected school A, B and C reveal that respondents do not teach indigenous music to their pupils because they have not learnt it at their Colleges. Taking children through indigenous Music and Dance lesson in the primary schools could help them live in harmony with each other to promote peaceful co- existence among the pupils and eventually it will be extended to adults in the community.

\section{Instructional materials used in Teaching Music and Dance}

Instructional materials are any materials used by the teacher to aid him or her to implement, enrich, deliver, support or assist in implementing any educational curriculum program of the school system.Instructional materials can be in print and non-print items that are rested to impact information to students in the educational process. Instructional materials play a very important role in the teaching and learning process. It enhances the memory level of the students and also enhances the learning achievement. Use of instructional materials can appeal to the individual attention by creating interest goal that will help the 
learner achieve direct effort and prepares a person to respond to similar situation in future.It is clear that effective instructions cannot be wellaccomplished without the use of instructional materials. Instructional materials provide the teacher with interesting and compelling platforms for conveying information since they motivate learners to want to learn more and more. Also, by providing opportunities for private study and reference, the learner's interest and curiosity are increasingly stimulated. Furthermore, the teacher is assisted in overcoming physical difficulties that could have hindered his effective presentation of a given topic. Instructional materials generally make teaching and learning easier and less stressful.

Respondents were asked to indicate the instructional materials used in teaching Creative Arts (Music and Dance) in their respective schools. Almost all complained about lack of Music textbooks, teachers' handbook and pupils' workbook. In school B, there was only one Creative Arts syllabus shared among six teachers. Contrarily school $\mathrm{C}$ had no Creative Arts (Music and Dance) Syllabus. Lack of teaching and learning materials (TLMs) such as drums, bells, rattles and clappers were a challenge in all schools. Nzewi (1999) asserts that one of the problems sub-Saharan African countries are grappling with is the lack of facilities for music teaching and learning. Akrofi (1988) confirms that equipment like stereos, television, and video tapes which are useful to enhance the teaching and learning of African music are non-existent in most of the schools in Ghana. It is clear from the above that Music Education is not a priority in our Primary Schools and Colleges of Education in Ghana.

Resources are the teaching materials and teaching aids that are necessary for smooth and effective delivery of the curriculum. Resources must be available in adequate quantities and accessible to learners in order for any Music and Dance programme to be ran effectively. In the case of Nanumba North District, the music resources in question include music instruments which are mainly traditional (that is, drums, atenteben, xylophones, dawule, clappers, rattles, dondo, CDs and CD players, TV sets and videos, instructor-manuals and learner work books, and chalk boards which are not readily available. Resources also include classrooms, teaching aids, and music specific needs.Tindall (1993) points out that one of the prerequisites for a good learning programme is a satisfactory edifice in which children could have plenty of space to learn and explore, and where adequate playing equipment could be set out. Where there are few resources and little expertise, the results can be disastrous. No matter how good the teaching may be, if the resources are poor or with no resources at all, learners will end up not having the best education and in most cases they will not learn. Onyango (1985) affirms that unfavourable teaching and learning conditions, coupled with the government's failure to address these conditions, are largely the reason for the difficulties confronting both students and teachers to be committed to their work.

Instructional materials according to Hargreaves, (1986) are essential tools that assist teachers in teaching. However, the materials in themselves cannot determine the objectives of the lesson. The study ascertains that a teacher with all instructional materials must also adopt a suitable approach as a means in carrying out a lesson. Lack of workbooks, drums, Music textbooks, Creative Arts syllabus as well as teachers' handbook was a major challenge noted about instructional materials. The researcher identified this through the interview process and has been confirmed through the researcher's observation in the three selected schools. My observation indicates that there is a great need for teaching and learning materials. In all the selected schools there were no teaching and learning materials in the school. Apart from having one blackboard in the classroom, there was nothing else available for Creative Arts (Music and Dance) lesson delivery. Creative Arts (Music and Dance) teachers in schools relied on the blackboard for the delivery of music lessons. There was no audio, video set, drums, percussions, Music and Dance textbooks in schools. Virtually there was nothing about Music and Dance instructional materials in the selected schools observed but one can only see the blackboard. Music education in Nanumba North District thus faces a significant challenge of finding appropriate ways of achieving its objective with such limited resources.

\section{Classroom Atmosphere}

During 9 lessons observed in schools A, B and C it was revealed that, the opportunity for pupils' participation was very good and many children were found involved in dancing. Pupils were seen clearly participating in almost all the lessons by way of singing and clapping. Smith et al. (1957) state that when children's interest is catered for by the teacher, their participation is high and this results in the achievement of the set objectives for the lesson. For effective classroom work, students should feel free to ask questions, 
discuss issues and be tolerant to opposing views and responses of their colleagues (Mankoe, 1997). The kind of classroom atmosphere teachers created for childrento learn Music and Dance as a component of Creative Arts during lessons observed, was very good. Teachers created a very good platform for smooth music and dance to take place and the eagerness on the part of the pupils was very encouraging. The implication is that there was openness and democratic atmosphere in all the lessons observed. Reseshine and Furst cited in Tamakloe et al (1996) state that democratic atmosphere situations provide opportunities for learners to learn the content of what is being taught. Tamakloe contend that teaching and learning resources emphasize particular points raised in the lesson more effectively than the teacher can emphasis with words in the lesson. The absence of this, therefore, means they would miss the full impact of the lesson.

\section{Impact of College Music and Dance on primary school}

Preparation of quality teachers to teach in the primary schools is the responsibility of the Colleges of Education. The Colleges are to train student teachers to be well equipped with the skills, content and pedagogical knowledge to effectively teach any subjects taught at the primary school level including Creative Arts (Music and Dance) subject. The contents and the methodology of Music and Dance at Colleges should have impact on the teacher trainees to be in position to implement Creative Arts (Music and Dance) curriculum. With the skills, content and pedagogy in place it would impact teachers to teach Music in the primary schools effectively. Arthur (1999), states that, when teachers are knowledgeable of the subject matter, it influences their interpretation of the curriculum intentions. An observation made on the teachers' knowledge of the subject matter from the three selected schools revealed that the teachers' knowledge of the subject matter in all the nine (9) lessons observed was not adequate. This implies that teachers observed were not knowledgeable in the facts and concepts relevant to the topics they treated. Thus, they tried putting forth their knowledge in the topic they treated in their lesson delivery. Gross et al. (1971) opines that teachers' knowledge of the subject matter promotes the implementation of an innovation.

Tamakloe et al (1996) state that among the competencies a teacher should exhibit to foster effective learning is the skill of teaching. As part of the observation reveals that the teaching skills demonstrated by the teachers in the presentation of their lessons were very poor, none of them taught any meaningful lesson in Music and Dance. This indicates that the teachers observed did not have any good record of teaching skills which could be employed to perform the teaching tasks related to activities which may be based on the amount of Music and Dance programme needed for the primary schools.

Farrant (1980), states that one of the characteristics of good teaching is the teaching method used by the teacher. From the observation of lessons made, the teachers' choice of teaching methods to ensure the achievement of the objectives of the lesson was not good. Most of the participants from the three (3) schools think that teaching and learning of Music and Dance is all about singing in the classrooms.

The quality of teaching in the schools depends on the quality of teacher preparation received at College. This preparation of Music and Dance teachers for primary schools should be well structured to be in harmony with what pertains in the Colleges of Education in terms of the subject matter. In other words, there should be a relationship between Music and Dance practised at the Colleges of Education and the contents in Creative Arts (Music and Dance) to enable teachers have full control over the subject matter. There should be a link between them. A teacher cannot be successful in his/her teaching of Music and Dance in primary school without the use of instructional materials. Instructional materials should be relevant to your topic that you are teaching, aid teacher in performing an activity. Materials such as drums, clappers, dewuro (bell), rattle, music textbooks, teachers' handbook, to mention a few should be readily available in primary schools for teachers of Music to use during their lesson. Teachers ought to be well prepared in both Music and Dance content and methodology at the Colleges, and there should be a relationship between Music taught at the Colleges and Music practiced in the primary school. The use of relevant instructional materials in teaching Music and Dance at the primary schools, then impact would be felt and seen by everybody.

\section{Summary}

The study delved into the influence of Music education in Colleges on the teaching of Music in the primary school. To achieve the set objectives for this study the following research questions were used to arrive at the findings. What training do the student teachers receive in preparation to teaching music in the Creative Arts syllabus, what is the relationship between Music Education at the Colleges of Education and the 
primary school, what kind of instructional materials are employed in the teaching and learning of Music at the basic school and to what extend does College Music impact the teaching of Music at the primary school?

Review of relevant literature in the research area was comprehensively done in the chapter two of this study. Areas like the curriculum, integrated curriculum, and importance of teaching music, dance and drama in the primary schools, the role of Music and Dance in primary school, the Creative Arts curriculum, and the role of the music educators in facilitating children's learning in music lessons were discussed. However, the major literature, Shulman (1986) that directed my discussion of this study was the preparation of student teachers or teachers knowledge in Music. Shulman (1986) argued that teachers' cognitive understanding of the subject matter, content and the relationships between such understanding and the instruction teachers provide for students could be the missing programme in educational research.

The qualitative method was used by the researcher and data were obtained through observations and interviews as the instruments. These instruments were employed to collect the data from the sampled schools. The findings of the study suggest that many primary school teachers in the teaching profession felt that the amount of training or the preparation that they have received in relation to teaching Music and Dance in Colleges of Education has been inadequate. Added to that, it has no relationship with what is in the Creative Arts syllabus (Music and Dance) thereby making teachers very handicap in teaching any lesson in Music and Dance. This is a matter for concern, the level of initial teacher training has been found to be the strongest determinant of the level of music education generalists provide (Temmerman, 1997) and affects teachers' ability to teach music adequately (Darling-Hammond, 2001).

In addition, it was found out that, there was no relationship in what teachers' studied at their various Colleges and the primary school in terms of Music contents. Creative Arts (Music and dance) is full of practical lessons but that of colleges is full of theories. Besides, the respondents were not taken through how to prepare scheme of work, preparation of lesson note, pedagogies or techniques of teaching Music and Dance, assessments and the others were not taught at the colleges.

An instructional material always provides teachers the best instructive and pedagogical approach to the teaching and learning of any subjects including Creative Arts (Music and Dance). Instructional materials such as musical instruments (drums, clappers), teacher's handbook, textbooks and workbooks for pupils to use were not readily available in the schools. This was making the work of teachers very difficult in terms of effective teaching.

To sum up, the research was about the influence of Music Education in Colleges on the teaching of Music in the primary schools. The literature by Shulman (1986) influenced this study, that is, teachers knowing the mastery of the subject matter (content) and pedagogical knowledge would go a long way in enhancing the teaching and learning of Creative Arts (Music and Dance). Inadequate teacher preparation in Colleges leads to the poor teacher preparation in Music and Dance in the primary schools. There was no relationship between Music contents in Colleges and the Creative Arts (Music and Dance) contents resulting in the misslink between the course content of teacher training institutions on one hand and the syllabus of the Creative Arts (Music and Dance) on the other. Unavailability of instructional materials in schools was also identified. Music education in colleges does not have any impact on the teachers to enable them teach Creative Arts (Music and Dance) effectively in their respective schools.

\section{Conclusion}

Based on the findings of the study the following conclusions were made. This study focused on the influence of music education in colleges on primary schools in some selected schools in the Nanumba North District Bimbilla in the Northern Region of Ghana. It became clear that primary school teachers unable to teach Creative Arts (Music and Dance) due to inadequate teacher preparation or training received at their various Colleges. This poor teacher preparation leads to lack of skills and knowledge on the part of teachers makes it difficult to teach Creative Arts (Music and Dance) in the primary school thereby making teacher's handicap in interpreting or executing the Creative Arts (Music and Dance) curriculum. Most of the information in Creative Arts (Music and Dance) is more of practical compared to the contents of Music at Colleges.

There was a gap between College Music and Dance and the Creative Arts (Music and Dance) in the primary school in terms of content. Teacher preparation ought to be given serious attention in Music and Dance at 
the Colleges of Education. Most teachers from the Colleges who teach Creative Arts (Music and Dance) at the primary schools in the Nanumba-North District had inadequate practical and theoretical background in the musical concepts. This is because what goes into the teacher preparation had no relationship or bearing on what the teachers are supposed to teach at the primary school levels.Ebeli (2016), opine that teachers are therefore required to lace theirlessons with musical activities to create an interesting environment and teachers must allow children to experience musical concepts rather than sessions or watching videorecordings of performances.

Music and Dance taught at Colleges should have a relationship with the Music at the primary schools. Specifically, teacher trainees are only provided with a very short learning experience which spans for just one semester, in which they develop just some few skills in music.

It should also be mentioned that the use of instructional materials impact teaching and learning of students and it was found out that the instructional materials was grossly inadequate and this negatively affects effective teaching and learning of Creative Arts (Music and Dance) in the primary schools.Ebeli (2016) suggested that where instruments are not available, learners should be encouraged to construct drums using empty tins as drum shells and plastic sheets as membranes. In view of this schools should endeavour to procure at least a set of three drums of varied pitches to serve all-purposes since such excuses should not deprive learners their right to enjoy school experience.

It came to light that, the curricula of music education at the Colleges of Education and that of primary schools were at variance. Also, the scope of contents of music education at the colleges of education was shallower compared to that of the primary schools. These setbacks, coupled with inadequate availability of teaching and learning resources for the implementation of music education at the selected primary schools made it difficult to observe any direct impacts. The study concludes that there was not much observed direct influence of Music education at the Colleges of Education on primary schools in the Nanumba North District.

\section{Recommendations}

This research among other things recommends the revision of the content of the Music and Dance programme in the Colleges of Education to reflect what is happening in the basic schools since this would go a long way to boost teachers' skills, knowledge and their mastery of contents and methodology level to help them discharge their duties as Creative Arts (Music and Dance) teachers in teaching of music.

Teacher education courses especially in Music and Dance at the Colleges should emphasize teachers' understanding of subject matter, content and the relationship between such understandings and the instruction teachers provide for student teachers. The mastery of the contents and the understanding of the methodology of the subject matter make teachers very effective.

In view of this, the researcher recommends that the Ghana Education Service in collaboration with the Ministry of Education should provide the necessary instructional material or resources to enhance the Creative Arts (Music and Dance) teaching and learning process in the primary schools.

In-Service Training and Workshops should be embarked upon for teachers who teach Creative Arts (Music and Dance) to enable teachers to be abreast with the content knowledge, pedagogical knowledge and practical skills needed for effective teaching of the curriculum.

Acknowledgement: Augustine Adjei (Dean of Students' Affairs), Missper Mawusi and Bridget Adom-Adjei.

\section{References}

[1.] Abrokwaa, C.K. (1999). "Indigenous Music Education in Africa" in Semali, Ladislaus M. andKincheloe, Joe L. (eds), What is Indigenous Knowledge. New York: Falmer Press.

[2.] Adejumo, C. O. (2002). Five ways to improve the teaching and understanding of art in the school. International Journal of Education \& the Arts vol.55(5).

[3.] Aduonum, A. (1980). A Compilation Analysis and Adaptation of Selected Generation Folk Tale Songs for Use in the Elementary General Class. Phd. Dissertation, Univ. of Michigan, Ann Arbor.

[4.] Akrofi, E. A. (1988). Is extracurricular music education going to displace curricular musiceducation in Ghana? The Oguaa Educator (Cape Coast, Ghana), vol. 9, October, pp. 12- 20. 
[5.] Aubrey, C. (1993). The Role of Subject Knowledge in the Early Years of Schooling, London: The Falmer Press, Vol.193, pp.2-7.

[6.] Ballantyne, J. (2000). Senior classroom music: Factors influencing subject choice. Queensland Journal for music education, Vol.7(1), pp. 39-54.

[7.] Balogun, D.A., Okon, S.E., Musaazi, J.C. S. \&Thankur, A.S. (1984).Principles and Practice of Education.London Macmillan Publishers.

[8.] Bamford, A. (2006). The WOW factor: Global research compendium on the impact of arts in education. New York: Waxmann Munster.

[9.] Bandura, A. (1986). Social Foundations of Thought and Action. New York: Prentice- Hall.

[10.] Bandura, A. (1977). Self-efficacy: Toward a unifying theory of behavioral change. Psychological Review, 84, pp.191-215.

[11.] Bandura, A. (1997). Self-Efficacy: The Exercise of Control, Freeman, New York.

[12.] Barry, N. H. (1992). Music and education in the elementary music methods class. Journal of Music Teacher Education, 2(1), pp.16-23.

[13.] Berg, B. L. (2001). Qualitative research methods for the social sciences. Allyn and Bacon: Needham Heights, MA.

[14.] Blacking, J. (1973).How Musical is Man? London: Faber \& Faber.

[15.] Bloomfield, A. \& Childs J. (2000). Teaching Integrated Arts in the Primary School: Dance, Drama, Music and the Visual Arts. London: David Fulton Publishers.

[16.] Bresler, L. (1993). Music in a double-bind: Instruction by non-specialists in elementary schools.Bulletin of the Council for Research in Music Education, Vol.115, pp.1-13.

[17.] Bryman, A. (2001). Social Research Methods, Oxford: Oxford University Press.

[18.] Burns, R.B. (2000). Introduction To research methods. London: Sage Publications Ltd.

[19.] Burton, B. (1987). How to Teach Primary Drama, (2nd Ed.). Melbourne: LongmanCheshire.

[20.] Buschner, C. (1994). Teaching Children Movement Concepts and Skills: Becoming a Master Teacher. Champaign: Human Kinetics Publishers,Inc

[21.] Catterall, J. S., et al. (1999). Involvement in the Arts and Human Development: General Involvement and Intensive Involvement in Music and Theatre Arts in applications (2nd ed.). Upper

[22.] Saddle River, NJ: Merrill Prentice Hall. Childhood Literacy vol.10 (4) 430-452. Retrieved February, 21st 2015 from http://ecl.sagepub.com/content/10/4/430.full.pdf+html

[23.] Chanunkha, L. (2005). Music Education in Malawi: The Crisis and the Way forward. PhD. Dissertation.Pretoria: University of Pretoria.

[24.] Cone, T. \& Cone, S. (2005). Teaching Children Dance.(2nd Ed.). Lower Mitcham:Human Kinetics.

[25.] CRDD. (1987). Suggested Cultural Studies Syllabus for Junior Secondary Schools (1-3years) Accra: Min. of Educ.

[26.] CRDD Trainers Manual (2007).Ghana Education Service. Accra: Premier Link Investment Ltd.

[27.] Creswell, J. W. (2003). Research design: qualitative, quantitative and mixed methods approaches (2nd ed.). Thousand Oaks: Sage Publications.

[28.] Creswell, J.W. (2008), Educational research: Planning, conducting and evaluating quantitative and qualitative research. New Jersey: Upper saddle River publications.

[29.] Curriculum Research and Development Division. (2007). Teaching Syllabus for Creative Arts (Primary 1-5). Ministry of Education, Ghana.

[30.] Darling-Hammond, L. (2000). How teacher education matters. Journal of Teacher Education, Vol.51, pp. 166-173.

[31.] Deasy, R. (2002). Critical links: Learning in the Arts and student academic

[32.] achievement and social development.Washinton DC: Arts Education Partnerships.

[33.] Durrant C. \&Welch G. (1995). Making Sense of Music: Foundation for Music Education. London: Cassell.

[34.] Dzorkpey, T.K. (2000). Training Music Teachers for Multicultural Education in SouthAfrica.Unpublishedthesis.University of the Orange Free State. 
[35.] Ebeli, E. A. (2015). Communication process in totoememusic of the Avatime people of Ghana.Int. J. Afr. Soc. Cultures Traditions Vol.3(5), pp.1-11.

[36.] Ebeli, E.A. (2016). Girl Child education and enrolment drive: The role of traditional music and dance. Journal of Music and Dance, Vol.6(3), pp. 20-26.

[37.] Eisner, E. W. (1994). What really counts in schools. Educational Leadership Vol.48 (5), pp10-17.

[38.] Eisner, E. (2002). The arts and the creation of the mind. New Haven: Yale University Press.

[39.] Evans, R. (1975). The Real Versus the Ideal: Gap in our School Music Programme. InNotes on Education and Research in African Music.No.2 I.A.S. Univ. of Ghana, Legon.

[40.] Farrant, J.S. (1980). Principles and practice of education. Harlow. Easex: Longman Group Ltd.

[41.] Feierabend, J. M, Saunders, T. C and Barbra N. F (2002). The Effects of Television Music Instruction on Kindergarten Students' Music Performance Skills.Bulletin of the Council for Research in Music Education, Vol.152, pp.64-73.

[42.] Fisher, C. (2004). Researching and Writing a Dissertation - For Business Students, Prentice-Hall, Englewood Cliffs, NJ.

[43.] Fiske, E. (Ed.) (1999). Champions of change:The impact of the arts on learning.

[44.] Washington DC: Arts Partnership \& President's Committee on the Arts and Humanities.

[45.] Flolu, E. J. (1993). The dilemma for music education in Ghana.British journal of Music Education, Vol.10, pp.111-121.

[46.] Flolu, J. \&Amuah, I. (2003). An Introduction to Music Education in Ghana for University and Colleges. Accra, Black Mask Limited

[47.] Gamble, S. (1988). The Elementary Classroom Teacher: An Ally for Music Education. Music Educators Journal, Vol.76 (1), pp. 25-28.

[48.] Gardner, H. (1985). Frames of Mind: The Theory of Multiple Intelligences. London: Paladin.

[49.] Gifford, E. (1993). The Musical Training of Primary Teachers: Old Problems, New Insights and Possible Solutions, British Journal of Music Education. Vol.10, pp. 33-46.

[50.] Green, L. S., Chedzoy, W., Harris, R. M., Naughton, C, Rolfe, L. \& Stanton, W. (1998).A Study of Student Teachers' Perceptions of Teaching the Arts in PrimarySchools.British Educational Research Journal,Vol.24 (1),pp.95-107.

[51.] Gross, N; Giacquinta, J; \& Bernstein, N. (1971). Implementing organizational innovations: A sociological analysis of planned educational change.New York: Basic Books.

[52.] Grossman, P. L., Wilson, S. M. and Shulman, L. S. (1989). 'Teachers of Substance: Subject Matter Knowledge for Teaching' in Reynolds, M. C. (ed., 1989) The Knowledge Base for the Beginning Teacher. Oxford, Pergamon, pp.24-28

[53.] Grossman, P. L. (1990). The making of a teacher. New York: Teachers' College Press.

[54.] Hargreaves, D. J. (1996).The Development of Artistic and Musical Competence. In I .Deliege. \&Sloboda, J. (Ed.) Musical Beginnings: Origins and Development of Musical Competence, (pp. 145-170) Oxford: Oxford University Press

[55.] Hargreaves, D. J.(1986).The developmental psychology of music.Cambridge University press.

[56.] Herbst, A., de Wet, J., \&Rijsdijk, S., (2005).A survey of music education in the primaryschools of South Africa's Cape Peninsula.Journal of Research in Music Education, Vol. 53(3), pp 260-283.

[57.] Herbst, A. (2007) AContemporary Study of Musical Arts, Informed by Indigenous Knowledge System Volume 4. Cape Town: Centre for Indigenous Instrumental African Music and Dance.

[58.] Holt, D. (1997). Hidden strengths: The case for generalist art teacher. In D. Holt (Ed.) Primary arts education: Contemporary issues (pp.84-95). London:Falmer Press.

[59.] Jeanneret, N. (1997). Model for Developing Pre-service Primary Teachers' Confidence to Teach Music.Bulletin of the Council for Research in Music Education, Vol.133, pp.37-44. http://www.jstor.org/stable/40318837

[60.] Jensen, E. (2002). Brain Compatible Strategies. (Australian Edition). Flagstaff Hill:Focus Education Australia Pty Ltd.

[61.] Joseph, D., \& Heading, M. (2010). Putting theory into practice: Moving from student identity to Teacher identity. Australian Journal of Teaching Education, Vol. 35 (3).Doi: 10.14221/ajte.2010v35n3.6. 
[62.] Kagan, D. (1992). Professional Growth Among Pre-service and Beginning Teachers. Review of Educational Research. Vol.62, pp. 129-169.

[63.] Kiggundu, E., \&Nayimuli, S. (2009). Teaching practice: A make or break phase for student teachers. South AfricanJournal of Education, Vol.29 (3), pp.345-358.

[64.] Kindler, A. M. (2008).Art, Creativity, Art Education and Civil Society.International Journal of Education and the Arts. Vol. 9(6).

[65.] Kyewune, J. (2002). Norms in a contemporary society: The case of Buganda. Paper presented at the Professor's Peace Academy (Kenya) regional conference, Mombasa, pp.15-18 Septembe

[66.] Loeffler, G. (2003). Creative Movement and Dance in Early Childhood Education.The Canadian Child Care Federation.[Online]. Available: www.cfcefc.ca/docs/cccf/00013_en.htm [17/09/05].

[67.] Major, T.E., \&Mannathoko, M.C. (2013).Listening to the voices of the post graduate diploma in education (Preservice) student teachers in Botswana.International Journal of Scientific Research and Application, Vol.1(2), pp.38-46.

[68.] Manford, R. (2007). Importance and the Benefits of the Arts in Education. In E. J. Flolu, M. P. Dzansi-McPalm\& M. O. Awoyemi (Eds.), Education in Ghana: Challenges for the 21st Century. Accra: Black Mask. pp. 1-12.

[69.] Mankoe, J.O. (1997). Notes on methods and materials for primary school teaching. Winneba, Department of Psychology \& Education.

[70.] Masoga, M.A. (2003). Establishing dialogue: thoughts on music education in Africa, Alternation.

[71.] McGreevy-Nichols, S. \&Scheff, H. (1995).Building Dances: A Guide to Putting Movements Together.Lower Mitcham: Human Kinetics.

[72.] McPherson, G. E., \& McCormick, J. (2006). Self-efficacy and music performance. Psychology of Music, Vol.34, pp.325-339.

[73.] Mills, J. (1997). Knowing the Subject Versus Knowing the Child: Striking the Right Balance forChildren Aged 7-11 Years. Research Studies in Music Education.Vol.9, pp. 29- 35.

[74.] Mills, J. (1995). Primary Student Teachers as Musicians.Bulletin of the Council for Research in Music Education. Vol.127. pp. 122-135.

[75.] Mills, J. (1989). Generalist primary teachers of music: A problem of confidence. British Journal of Music Education, Vol.6(2), pp. 125-138.

[76.] National Curriculum Council (NCC) (1992). Music in the National Curriculum: A Report to the Secretary of State for Education and Science on the Statutory Consultation for. Attainment Targets and Programmes of Study in Music. York: National Curriculum Council

[77.] Ngidi, D.P.\&Sibaya,P.T.(2003). Student teacher anxieties related to practice teaching. South African Journal of Education, Vol. 23, pp.18-22.

[78.] Nketia, J. H. K. (1999). A Guide for the Preparation of Primary School African Music TeachingManuals. Accra: Afram Publications.

[79.] Nketia, J.H.K. (1967). The Place of Authentic Folk Music.InMusic Educators Journal, No. 54.

[80.] Nketia, J.H.K. (1997). Cultural Diversity and Music Education in Ghana. A paper read at the Congress of the International Music Council, Arhus, Denmark.

[81.] Nzewi, M. (1988). State of literary music in Nigeria: A review.Nigeria Magazine, Vol.56(3\&4), pp. 5-24.

[82.] Nzewi, M. (1999).Strategies for music education in Africa.Towards a meaningful progression from tradition to modern. In: VAN NIEKERK, C. (ed.). Conference proceedings of 23rd International Society for MusicEducation World Conference. Pretoria: Unisa, pp.456-486.

[83.] Nzewi, M. (2001). Music education in Africa: mediating the imposition ofwestern music education with the imperatives of the indigenous Africanpractice. In: VAN NIEKERK, C (ed.). Conference proceedings of the PASMEConference held in Lusaka, Zambia, 21-25 August. PASMAE: 2001, pp.18-47.

[84.] Nzewi, M. (2007).A Contemporary Study of Musical Arts Informed by African Indigenous Knowlwedge Systems: Illuminations, Relections and Explorations, Vol.4. South Africa: Ciimda. Omolo-Ongati, R.

[85.] Nzewi, M. (2003).Acquiring Knowledge of the Musical Arts in Traditional Societyin A. N.Herbet, Musical Arts in Africa: Theory, Practice and Education (pp. 13-37). Pietermaritzburg: Unisa Press. 
[86.] Ogbe, G.K. (1975). Educating the Musical Child.In Notes on Education and Research in African Music.No.2 I.A.S Univ. of Ghana

[87.] Opondo, P. (2000). Cultural practices in Kenya. Arts Education Policy Review, vol. 101(5), pp. 1824.

[88.] Oreck, B. (2004). The artistic and professional development of teachers.Journal of Teacher Education, Vol.55(1), pp. 55-69.

[89.] Osuala, E. C. (2001). Introduction to Research Methodology. .Nsuka: Rex Printing Ltd.

[90.] O'Toole, J \& Dunn, J. (2002).Pretending to Learn: Helping Children Learn throughDrama. Frenchs Forest: Pearson Education Australia.

[91.] Page, N. (1995).Music as a Way of Knowing. USA: Stenhouse Publishers.

[92.] Pajares, F. (2003). Self-efficacy belief, motivation, and achievement in writing: A review of the literature. Reading and Writing Quarterly, Vol.19, pp.139-158.

[93.] Perry, R, (2004). Teaching Practice for Early Childhood.A guide for students. [Online] Available: http://www.Routledge.com catalogues./0418114838.pdf. on Retrieved 13 June 2012.

[94.] Pintrich, P. R., \&Schunk, D. H. (2002). Motivation in education: Theory, research, andapplications (2nd ed.). Upper Saddle River, NJ: Merrill Prentice Hall.

[95.] Reimer, B. (1989). A philosophy of music education.Englewood Cliffs: Prentice Hall, second edition.

[96.] Renes, R.W. (1982). Personal administration in education. Englewood Cliffs, New jersey: Prentice Hall.

[97.] Rocheleau, M (2009). Social Function of African Music. Viewed 4 April 2014, http://voices.yahoo.com/social-function-african-music-3403568.html?cat=37.

[98.] Ross. M. (1984). What's Wrong With School Music? British Journal of Music Education.Vol.12, pp.185-201.

[99.] Russell-Bowie, D. (1993). Where is Music Education in Our Primary Schools. Research Studied in Music Education. Vol. 1, pp.52-58.

[100.] Russell-Bowie, D. (2009). MMADD about the arts:An introduction to primary arts education.Frenchs Forest, NSW: Pearson Education Australia.

[101.] Russell, J. (1965). Creative Dance in the Primary School. London: MacDonald \&Evans Ltd.

[102.] Short, K.G., Schroeder, J., Laird, J.,Kauffman, G., Ferguson, M.J., and Crawford, ～K.M. (1996). Learning together through inquiry: From Columbus to integrated curriculum.Portland, ME: Stenhouse.

[103.] Shulman, L. S. (1986). Paradigms and research programs in the study of teaching: A contemporary perspective. In M. C. Wittrock (Ed), Handbook of research on teaching. (3"' ed., pp. 3-36). New York: Macmillan

[104.] Shulman, L. S. (1986). Those who understand: Knowledge growth in teaching. Educational Researcher, Vol.15 (2), pp. 4-14.

[105.] Shulman, L.S. 1987. Knowledge and teaching: Foundations of new reform. Harvard EducationalReview, Vol.57(1), pp. 1-22.

[106.] Smith, B.O.; Stanley, M.O., Shores, J.H. (1957).Fundamentals of curriculum development.New York: Harcourt, Brace \& World Inc.

[107.] Solbu, E (1998). A Performance Perspective. In Lundquist, B \&Szego, R (eds.), Musics of theWorld's Cultures, Callaywa International Resource Centre for Music Education, Perth, WA, pp. 29-37.

[108.] Stanton, H. E. (1979). Developing Confidence in Student Teachers.Forum of Education. Vol.38(2), pp.9-14.

[109.] Stoll, L., Fink, D. \& Earl, L. (2003).It's about Learning (and it's about time): What'sin it for schools? London: Routledge Falmer.

[110.] Sun, M. (1993). EgitselMuzikOgretimiIn Say, A. (Edt) MuzikEgitimi. Ankara: MuzikAnsiklopedisi Yayinlari.

[111.] Swanwick, K. (1988). Music Mind and Education. London: Routledge.

[112.] Swanson, B.R. (1969). Music in the Education of Children.(3rd Ed.). Belmont:Wadsworth Publishing Company, Inc. 
[113.] Tait, M. J. (1992). 'Teaching Strategies and Styles' in Colwell, R. (ed). Handbook of Research on Music Teaching and Learning: A Project of the Music Educators National Conference, New York: Schimer Books, pp. 525 - 535.

[114.] Tamakloe, E. K., Attah, E. T, Amedahe, F.K. (1996). Principles and methods of teaching, Accra. Black Mask Limited.

[115.] Temmerman, N. (1997). An investigation of undergraduate music education curriculum content in primary teacher education programmes in Australia. International Journal of Music Education, Vol.30, pp.26-34.

[116.] Tewiah, M. (1994). Forty years of service: The story of Peki Training College. Daily Graphic.

[117.] Tindall, W. (1993). Early childhood education: a vital component in Bophuthatswana education system. PopaganoVol.4(1),pp.16.

[118.] Ucan, A. (1987). Music Education in Turkey in Republican Period. Turkish Review: Quarterly Digest, Vol.2 (8), pp.75-89.

[119.] UNESCO (2014a).Education. $\quad$ Viewed 4014 , http://www.unesco.org/new/en/education/themes/leading-the-international- $\quad$ agenda/humanrightseducation/resources/projects/teaching-respect-for-all/.

[120.] UNESCO (2014b).Intangible Cultural Heritage.Viewed $8 \quad$ April 2014, http://en.unesco.org/themes/intangible-cultural-heritage.

[121.] Wilson, J. \& Wing Jan, L. (2003).Focus on Inquiry: A Practical Approach to Integrated Curriculum Planning. Carlton: Curriculum Corporation.

[122.] Zimmerman, B. J. (1995). Self-efficacy and educational development. In A. Bandura, (Ed.), Selfefficacy in changing societies (pp. 202-231). New York: Cambridge University Press. 